lan tutkimuslaitoksen monisteita nro 5. Joensuu: Joensuun yliopisto.

- 2010: Entisen esivallan alle uusille elosijoille. Ortodoksikarjalaisten ja inkeroisten poismuutto 150o- ja 160o-luvuilla. Joensuu: Pohjois-Karjalan historiallinen yhdistys.

SKVR = Suomen kansan vanhat runot. URL: https://skvr.fi/ (15.1.2019).

Stepanova, F. V. 2006: Русский женский антропонимикон в культурно-генетическом аспекте: диссертация на соискание ученой степени кандидата филологических наук. Краснояр. гос. ун-т. Лесосибирск, 2006. http:// www. lib.ua-ru.net/diss/cont/180473.html

(23.12.2018).

Tupikov, N. M. 1903: Словарь древнерусских личных собственных имен. Санкт-Петербург: Типография И.Н. Скороходова.

Turunen, Aimo 1979: Kalevalan sanat ja niiden taustat. Lappeenranta: Karjalaisen Kulttuurin Edistämissäätiö.

Virtaranta, Pertit 1972: Polku sammui. Vienalaiskylien vaiheita rajan molemmin puolin. Helsinki: Kirjayhtymä.

1992: Tverinkarjalaisista nimistä. Suomalais-Ugrilaisen Seuran Toimituksia 209. Helsinki: Suomalais-Ugrilainen Seura.

\title{
Puhuiko Suomen sivistyneistö kirjakieltä?
}

Kaksikin melko hiljattain, vuonna 2016 ilmestynyttä kirjaa, Erkki Lyytikäisen $\mathrm{Sa}$ notaan tyyliin näin ja Lari Kotilaisen Kielen elämä, toistaa ja siten pitää yllä sitkeää myyttiä, että ainakin melkein koko suomalainen sivistyneistö noin 90-100 vuoden ajan (1870-1880-luvulta 1960-, ellei jopa 1970-luvulle) käytti puhekielenään kielioppien normeja tiukasti noudattavaa kirjakieltä. Tämä käy ilmi seuraavista katkelmista:

Tähän vaihtoehtoon innokkaimmat ruotsinkieliset fennomaanit tarttuivat. He opettelivat sananmukaisesti puhumaan kirjakieltä. Tämä merkitsi sitä, että sivistyneistön puhekieleksi vakiintui kirjakieli sadan vuoden ajaksi. (Lyytikäinen 2016: 207.)

Suomessa yhteiskuntaluokkien statuseron ilmaisemiseen syntyi uusia kei- noja. Kun ei puhuttu enää eri kieliä [= ruotsia ja suomea], alettiin puhua samaa kieltä eri tavalla. [- - ] Kun ruotsinkielinen sivistyneistö alkoi opetella suomea, mallina oli kirjakieli. [- - ] Häviäjiä olivat tavalliset murteet tai toisin termein luonnollinen puhuttu suomi, joka jäi paitsioon lähes sadaksi vuodeksi. (Kotilainen 2016: 149-150.)

Menen lähteille asti (ad fontes): viime vuosikymmenten keskusteluun tämän näkemyksen toi ja sitä on useimmin ja selvimmin pitänyt esillä professori Heikki Paunonen. Lainaan hänen puheenvuoroistaan kahta:

Jatkokehityksen kannalta ratkaisevaa oli, että normatiivisen puhekielen vaatimus saavutti 1800 -luvun lopussa vielä suhteellisen vähälukuisen suomalaisen sivistyneistön kokonaisuu- 
dessaan. Samoin merkittävää oli, että normatiivisuus tuli koskemaan paitsi virallista juhlapuhekieltä myös epävirallista arkipuhekieltä. (Paunonen 1993: 85.)

- - vasta nyt [sic - 1993!] on Suomessa kehittymässä se kielimuoto, joka 180o-luvulla jäi syntymättä, nimittäin epävirallinen puhuttu yleiskieli. (Mas. 88.)

Tullakseen keskenään kielellisesti tasa-arvoisiksi [180o-luvulla ja vähän sen jälkeen] suomalaisten tuli luopua omimmasta kielestään, koti- ja lapsuusympäristön käyttämästä murteesta. (Paunonen 1994: 27.)

Ratkaisevana seikkana on ollut kontrasti kirjakielisen puhekielen kanssa. (Mas. 26.)

Ehkä merkittävin muutos on kuitenkin se, että suomalainen puhekieli on irtautunut kirjakielestä; se on alkanut elää omaa elämäänsä. (Mas. 27.)

Väitettä, että Suomen sivistyneistö on kauttaaltaan arkisessakin puheessaan käyttänyt norminmukaista kirjakieltä ja vain sitä, on ennenkin arvosteltu (Kettunen 1909; Koivusalo 1997 [1982]; Rintala 1992; Hurtta 1999), mutta kun Lyytikäinen ja Kotilainen sen näin kategorisesti ja kyseenalaistamatta jälleen toistavat, on aihetta palata asiaan.

Tutkimuksia asiasta on jälkeenpäin vaikea tehdä; seuraavassa nojaan etenkin omiin muistikuviini vanhemmista sukulaisistani ja myös muiden heitä koskeviin muistoihin ja sitaatteihin.

Voin lukea itseni vanhaan sivistyssukuun: kun ikäluokassani - vuonna 1960 syntyneissä - ja sitä ympäröivissä oli yhä paljon sukunsa ensimmäisiä ylioppilaita, kuuluin itse niiden silloin harvojen joukkoon, joitten molemmat vanhemmat ja myös kaikki neljä isovanhempaa olivat ylioppilaita. Vanhempani päättivät koulunsa 1940-luvulla, isovanhempani 1900ja 1910-luvulla; ainakin isovanhempani siis olisivat ilman muuta eläneet aikaa, jona sivistyneistö Paunosen (> Lyytikäisen ja Kotilaisen) väitteen mukaan käytti norminmukaista kirjakieltä puhekielenään.

Molemmat isoisäni kuolivat liian varhain, jotta muistaisin heidän puhettaan. Isoäitieni puhetta sen sijaan kuulin 14. ja 18. ikävuoteeni asti, ja kysymykseen, puhuivatko he arkielämässään kirjakieltä, yksiselitteinen vastaus on: eivät. Äidinäitini oli syntynyt vuonna 1895 Nurmeksessa, ja äitinikin muistojen mukaan hänellä "oli rikas itämurteinen kieli" (Anhava 2006: 12). Hänen puheensa itäisyyksistä muistan itse muun muassa muodot ylläällä ja allaalla 'ylhäällä, alhaalla' (varsin yleisinä), suella 'sudella' (ja muita $d: n$ katoedustuksia) ja pelottammaan, olevinnaan. Isänäitini taas oli syntynyt Kurikassa vuonna 1896 mutta kävi oppikoulun ja tuli ylioppilaaksi Oulussa; niinpä hänen puheessaan kuului sekä etelä- että pohjoispohjalaisia piirteitä: silimät, ainua, Herra hallikkoon, eteläpohojalaanen, se ellää vieläkin, saat kuolemantauvin ynnä muita vastaavia.

Olennaisempaa kuin yksittäiset murrepiirteet on se, että kummankin isoäitini puhe oli arkista, osin murreväritteistä yleissuomea. Monikon 1. ja 3. persoonan inkongruenssi (me mennään, pojat tulee), se persoonapronominina (pro hän), omistusliitteiden poisjäänti persoonapronominin genetiivin kanssa ja muut vastaavat piirteet esiintyivät heidän arkipuheessaan yhtä lailla kuin nuorempienkin. Päinvastainen asiaintila (norminmukaisen kirjakielen puhuminen) olisi varmasti lapsena kiinnittänyt huomiotani ja oudoksuttanut; jotkin edellä mainitut murrepiirteet kummastuttivatkin.

Isoäitini tunsin tietenkin vain heidän vanhuudenpäivinään, mutta tuskinpa he 
vasta eläkeiässä olivat alkaneet puhua arkisuomea. Molemmat olivat olleet opettajia (toinen kotitalous-, toinen piirustuksenopettaja) - siis ammatissa, jossa kuului olla kielellisenäkin esikuvana. Heidän vuotensa perheenäiteinä osuivat 1920-40-luvulle - aikaan, joka Paunosen (> Lyytikäisen ja Kotilaisen) mukaan oli sivistyneistön kirjakielisen puheen valtakautta. Tällöin olisi kirjakielen pitänyt olla heidän silloin varttuneiden lastensakin, siis vanhempieni, puheen mallina. Tähän päästyäni ei ketään yllättäne, että näin ei ollut.

Täydennän vielä. Äidinäitini Aunesisar ("Ansku"), hänkin 1890-luvulla syntynyt, toimi puutarhaopettajana pääosin Itä-Suomessa ja asui eläkevuosinaan Kuopiossa; hänen puhetavastaan tuumin jo pikkupoikana: "Ansku-täti puhuu savoa." Heidän vanhin veljensäkin oli opettaja (jopa äidinkielen-); häntä en itse ehtinyt tavata, mutta häneltä lainattiin monesti lausumaa kahdesta veljestään: "Kaatu vappaussovassa." Toiselta veljeltä, metsänhoitajalta, jäi suvun muistoihin tokaisu, jonka hän sanoi lähtiessään kyläkauppaan vaihtamaan kuulumisia: "Lähen tästä Hinkkasen puotiin syleksimmään." Kuten ammateista näkyy, isoäitini sisaruksetkin olivat käyneet opintien.

Kirjoitukseni alussa lainaamani Lyytikäisen (mutta alkuaan siis Paunosen) päätelmä ei päde: kun 1870-80-luvun ruotsinkieliset fennomaanit opettelivat "sananmukaisesti puhumaan kirjakieltä", tämä ei merkinnyt sitä, että "sivistyneistön puhekieleksi vakiintui kirjakieli sadan vuoden ajaksi”. Näin ei ole edes voinut olla, sillä tilanne muuttui hyvin pian.

Ei ole helppoa määritellä, ketkä oikein kuuluivat "sivistyneistöön", mutta ajan oloissa sangen hyvä kriteeri oli ylioppilastutkinto. Jo 1900-luvun alussa, vain parin vuosikymmenen mentyä fennomaanien kielenvaihdoksen ajoista, oli suomenkielisten ylioppilaitten selvä enemmistö oppinut suomensa luonnonmenetelmällä kotipuolessaan, kukin omalla murrealueellaan, eikä suinkaan suomenruotsalaisten kielenvaihtajien kodeissa. Paunosen mukaan ruotsalaisfennomaanien esikuvan voima ja paino saivat eri puolilta Suomea opintielle lähteneet syntymäsuomenkielisetkin omaksumaan muodollisen kirjakielen jokapäiväiseksi puheekseen. Sen valossa, miten itse kuulin isoäitieni ja heidän ikäistensä sukulaisten puhuvan, ja vielä enemmän sen pohjalta, mitä olen muilta sukulaisiltani aiheesta kuullut, en voi tähän uskoa.

\section{JAAKKO ANHAVA anhavajaakko@gmail.com}

\section{Lähteet}

Anhava, Helena 2006: Toimita talosi. Muistijälkiä. Helsinki: Otava.

Hurtta, Heik i 1999: Variaatiotutkimuksen myytit ja stereotypiat. - Urho Määttä, Pekka Pälli \& Matti K. Suojanen (toim.), Kirjoituksia sosiolingvistiikasta. Folia Fennistica \& Linguistica 22. Tampere: Tampereen yliopiston suomen kielen ja yleisen kielitieteen laitos.

Kettunen, Lauri 1909: Suhteemme kirjakieleen. - Virittäjä 13 s. 165-168.

KoIvusalo, Esko 1997 [1982]: Kirjakieli ja murteet. - Kielen aika s. 32-35. Kotimaisten kielten tutkimuskeskuksen julkaisuja 92. Kielenkäytön oppaita 2. Helsinki: Edita.

Kotilainen, Lari 2016: Kielen elämä. Helsinki: Siltala.

LYYTIKÄINEN, ERKкI 2016: Sanotaan tyyliin näin. Helsinki: Gaudeamus.

Paunonen, Heikri 1993: Suomen mieli oikea kieli. - Virittäjä 97 s. 81-88.

_ 1994: Kielen normit ja kielen ohjailun normit. - Tiede \& edistys 1/1994 S. 17-28.

Rintala, Päivi 1992: Suomen kirjakielen normeista. - Sananjalka 34 s. 47-66. 